\title{
Corrigendum
}

\section{A CULTURE OF KINSHIP: CHINESE GENEALOGIES AS A SOURCE FOR RESEARCH IN DEMOGRAPHIC ECONOMICS-CORRIGENDUM}

\author{
Carol H. Shiue
}

doi:10.1017/dem.2016.24

Published by Cambridge University Press, November 2016.

On page 476 of the text, in the second paragraph it states: "In comparison, the percent of individuals who can be linked in the Chinese Eight Banner Registers is $14.54 \%$ or $24.76 \%$ for one generation, depending on whether one considers Liaoning or Heilongjiang Province [Dong et al. (2015)]." This should instead read: "In comparison, the percent of individuals who can't be linked in the Chinese Eight Banner Registers is $14.54 \%$ or $24.76 \%$ for one generation, depending on whether one considers Liaoning or Heilongjiang Province [Dong et al. (2015)]."

The authors apologise for this error.

\section{REFERENCE}

Shiue, C.H. (2016) 'A culture of kinship: Chinese genealogies as a source for research in demographic economics', Journal of Demographic Economics, 82(4), pp. 459-482. doi: 10.1017/dem.2016.24. 